\title{
AuCd 合金のマルテンサイトの結晶構造と中性子散乱
}

\author{
帝京大学理工学部 大庭卓也
}

\section{Takuya OHBA: Crystal Structure of AuCd Martensite and Neutron Scattering}

The AuCd is one of the typical alloys which show martensitic transformation. There are two distinct martensites called $\gamma_{2}$ ' and $\zeta_{2}$ ' phases appearing proximate to the composition of $\mathrm{Au}_{52.5} \mathrm{Cd}_{47.5}$ and $\mathrm{Au}_{50} \mathrm{Cd}_{50}$, respectively. The crystal structure of $\zeta_{2}$ ' martensite was solved and it was described to be a superposition of transverse waves whose poralization is $\langle 1 \overline{1} 0\rangle$ and wave vector is $\langle 110\rangle$. The phonon dispersion relations were observed for $\mathrm{Au}_{52.5} \mathrm{Cd}_{47.5}$ and $\mathrm{Au}_{50.5} \mathrm{Cd}_{49.5}$ overcoming the difficulty of strong absorption of neutron with an isotope ${ }^{114} \mathrm{Cd}$. The phonon softening behaviors were observed in addition to the peculiar behavior on $\mathrm{Au}_{52.5} \mathrm{Cd}_{47.5}$.

\section{1. はじめに}

マルテンサイト変態はよく知られた変態でありながら, 歴史的に金属の組織観察から発展してきたため,多くの 分類分けがなされ, 初心者にはとっつきにくいところも ある．そこでまずマルテンサイト変態の特徴と最近の話 題のいくつかを紹介し, 次に本論文の主題である結晶構 造と中性子散乱の話に移っていくことにする.

マルテンサイト変態は鋼の硬化に利用されるなど, 古 くから知られている.また, 形状記憶合金で知られてい る形状記憶効果はマルテンサイト変態を利用したもので あり, 工学的に広く利用されている. マルテンサイト変 態は表面に現れる特徵的な組織に注目し，いわゆる結晶 学的な研究が多く行われている. マルテンサイト変態に 見られる特徵には, 次のようなものがある.1)（1）表面起 伏や形状変化が見られる，(2) 晶癖面といわれるマルテ ンサイト相と高温相 (母相といわれる)の界面が特定の面 として存在する，(3) 結晶方位関係を持っている，(4) 双晶や積層欠陥のような欠陥が不可避的に導入される (これを格子不変変形という)，(5）無拡散変態である.マ ルテンサイト変態の研究は日本では先駆的な研究が多く なされ, 組織に着目したマクロな結晶学的な研究ともい えるマルテンサイト変態の現象論的理論として知られて いるものも，多くの成功を抢さめている．2)-5)

統計熱力学的な観点から, マルテンサイト変態のメカ ニズムに関わった研究も盛んに行われている。この説明 には多少の言葉の説明が必要なので簡単に言葉の説明を しながら話を進めていく．まず，熱による変態駆動力と 変態によって生じる弾性的な力の兼ね合いから熱弾性型, 非熱弾性型と分類されている.6), 7)一般的に熱弾性型と呼
ばれているものは変態の際の温度ヒステリシスが小さく， 形状記憶合金として利用されているのはこのタイプのも のである. 非熱弾性型の典型としては鉄系の物質があり, 大きな温度ヒステリシスを持っている．また，温度に対す る変態の進み方から, 温度を一定にしておいても変態が 進む等温変態と, 温度を下げる事によって変態が進む非

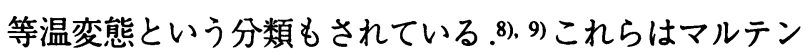
サイト変態の核生成と成長の問題と関わっている.最近, 掛下ら 100 により等温変態と非等温変態に関して統一的な 理解がなされるようになり，新たな展開が見えてきてい る.これは変態の潜伏時間という問題 111 ともかかわって いる.さらに, 変態に前駆してマルチバリアントが生成し ている方がエネルギー的に得であるという理論や，双晶 境界の構造とのかかわりなど 12 , 13) も問題になっている.

原子レベルのミクロな立場にたつと, マルテンサイト 変態は無拡散変態で起こる変位型変態として知られ, 一 次の相変態の代表的なものとして知られている. 原子レ ベルで考えた変態のメカニズムについては, マルテンサ イト相と母相との結晶方位関係がある事から，ある程度 の推察がなされてきた. 多くの $\beta$ 相合金では母相の立方 晶面がマルテンサイト相の稠密面になるような変態メカ ニズムを考えてきた。このなかでフォノンのソフト化と いう考え方は魅力的な考え方の一つであり，中性子散乱 の非弾性散乱によるフォノンの測定もなされている．し かしフォノンのソフト化とマルテンサイト相の結晶構造 とが必ずしもよい一致を示しているわけではない.14)- 16) また, X線による研究もなされ, 前駆現象として弾性散乱 が観察され，それらがブリルアンゾーンの周期性を持っ ていないという報告もなされている.17)この結果から山田 らによるMLR モデル 18), 19)なども提案されている. 
$\mathrm{AuCd}$ 合金はマルテンサイト変態をする典型的な合金 として知られ, 変態の温度ヒステリシスは小さく, 熱弾 性型と分類されるものである.この AuCd 合金の $1 ： 1$ 付 近の母相の結晶構造は $\mathrm{CsCl}$ 型の構造であり，マルテンサ イト相にはわずかな組成の違いにより，二つのまったく 異なった相が現れる。一つは $\gamma_{2}{ }^{\prime}$ 相といわれ $\mathrm{Au}_{52.5} \mathrm{Cd}_{47.5}$ 付 近に,もう一つは张相といわれ $\mathrm{Au}_{50} \mathrm{Cd}_{50}$ 付近に現れる. マルテンサイト変態の現象論的理論と呼ばれている研究 に関しても，AuCdは最初に適用された合金のひとつであ る.4)古くから多くの研究がなされ，それらの相の存在は 知られていながら, 特にら ${ }_{2}^{\prime}$ 相については, その結晶構造 は未知のままであった。

この報告では, 長いあいだ結晶構造が未知であった $\zeta_{2}^{\prime}$ マルテンサイト相の結晶構造, および $\gamma_{2}{ }^{\prime}$ マルテンサイ ト相とそれらの中性子散乱の最近の研究結果について述 ベる。

\section{2. $\zeta_{2}{ }^{\prime}$ 相 $\mathrm{Au}_{50.5} \mathrm{Cd}_{49.5}$ と $\gamma_{2}{ }^{\prime}$ 相 $\mathrm{Au}_{52.5} \mathrm{Cd}_{47.5}$ の結晶 構造とマルテンサイト変態}

$\zeta_{2}{ }^{\prime}$ マルテンサイト相は 1940 年に Köster と Schneiderに よりbctであるとの報告がなされた.201955 年にWilkens により菱面体的に変形した $\mathrm{B} 2(\mathrm{CsCl}$ 構造)であるという 報告があり，その後も多くの報告がなされ文献 21)にま とめられている. 1975 年には Vatanayan と Hehman22)によ って Trigonal の $P \overline{3} 1 m$ であるとの報告があるが, いわゆる 結晶構造解析の信頼因子としての R 因子の記述もなく， その結果に疑問が持たれていた。このような中，われわ れは応力誘起の方法によってマルテンサイト相の単結晶 の作製に成功し, 結晶構造解析を行った。そ結果は空 間群がP3で単位胞内に 18 個の原子を含んでいる構造で ある事がわかった.23)表 1 に結晶学的パラメータと原子位

表 $1 \zeta_{2}{ }^{\prime}$ 相 $\mathrm{Au}_{50.5} \mathrm{Cd}_{49.5}$ の結晶学的パラメー夕と原子位置. (Crystal data and atomic parameters of $\zeta_{2}{ }^{\prime} \mathrm{Au}_{50.5} \mathrm{Cd}_{49.5 .}$ )

\begin{tabular}{ll}
\multicolumn{2}{c}{ Crystal Data for $\zeta_{2} \mathrm{Au}_{50.5} \mathrm{Cd}_{49.5}$} \\
\hline Space Group & $\mathrm{P} 3$ \\
& Trigonal \\
\hline Lattice Constants & $\mathrm{a}=8.095(3) \AA$ \\
& $\mathrm{c}=5.794(6) \AA$ \\
\hline & 18 atoms/cell \\
\hline
\end{tabular}

The Final Atomic Parameters for $\zeta_{2}{ }^{\prime} \mathrm{Au}_{50.5} \mathrm{Cd}_{49.5}$

\begin{tabular}{ccccc}
\multicolumn{5}{c}{ The Final Atomic } \\
\hline Site & $\mathbf{X}$ & $\mathrm{y}$ & $\mathrm{z}$ & $\mathrm{B}$ \\
\hline $\mathrm{Au}(1 \mathrm{a})$ & 0 & 0 & 0 & $1.6(2)$ \\
$\mathrm{Au}(1 \mathrm{~b})$ & $1 / 3$ & $2 / 3$ & $0.151(2)$ & $1.0(2)$ \\
$\mathrm{Au}(1 \mathrm{c})$ & $2 / 3$ & $1 / 3$ & $0.000(1)$ & $1.6(2)$ \\
$\mathrm{Au}(3 \mathrm{~d})$ & $0.3333(9)$ & $-0.0192(8)$ & $0.416(1)$ & $0.9(1)$ \\
$\mathrm{Au}(3 \mathrm{~d})$ & $0.6921(7)$ & $0.0253(7)$ & $0.708(2)$ & $1.1(1)$ \\
$\mathrm{Cd}(1 \mathrm{a})$ & 0 & 0 & $0.507(3)$ & $0.5(2)$ \\
$\mathrm{Cd}(1 \mathrm{~b})$ & $1 / 3$ & $2 / 3$ & $0.650(4)$ & $1.2(3)$ \\
$\mathrm{Cd}(1 \mathrm{c})$ & $2 / 3$ & $1 / 3$ & $0.506(3)$ & $0.8(3)$ \\
$\mathrm{Cd}(3 \mathrm{~d})$ & $0.335(2)$ & $-0.022(2)$ & $0.913(3)$ & $1.6(2)$ \\
$\mathrm{Cd}(3 \mathrm{~d})$ & $0.680(1)$ & $0.014(1)$ & $0.211(3)$ & $0.8(1)$ \\
\hline $\mathrm{R}=7.8 \%, \mathrm{wR}=4.1 \%$ & & &
\end{tabular}

置座標を示し, 図 1 (a) にその模式図を示す. $c_{\mathrm{t}}$ 面の積層 で表現すると図1(b) のようになる. $z=0$ の面では+の 印であらわされた $\mathrm{Au}$ 原子が $z=0$ の面から $c_{\mathrm{t}}$ 軸方向へ変 位しており，その上の面にある Cd 原子が矢印で示され ているように外側に押しやられている．下にある Cd原 子は逆に空間を埋めるように集まってきている．同様な 変位は $z \sim 0.5$ の面の+印で示されているCd 原子とその 周りの原子にも見られる.これらの変位によっても原子 間距離は $2.83 \sim 2.99 \AA$ 程度と金属の原子半径から無理の ない值になっている。

この結晶構造解析の結果から原子レベルでの変態のメ

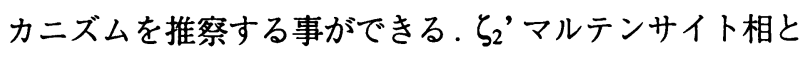

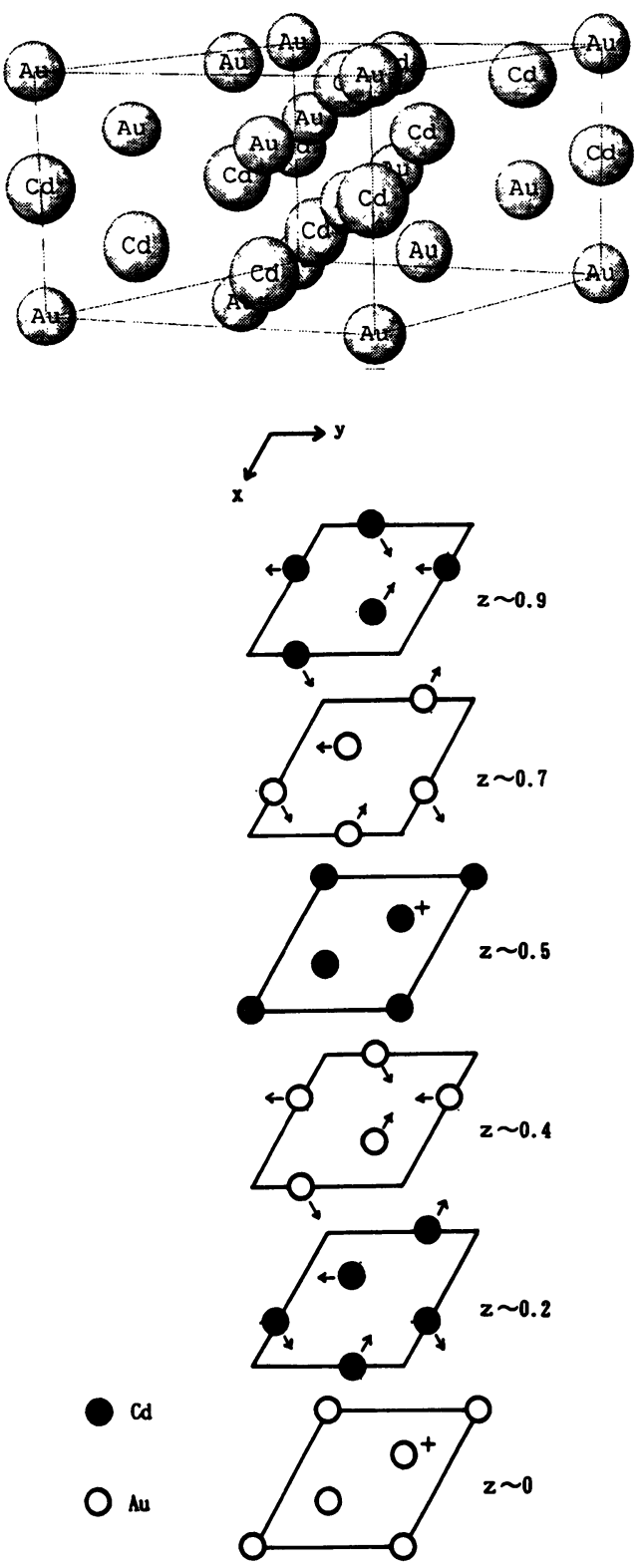

図 1 (a) $\zeta_{2}{ }^{\prime}$ 相 $\mathrm{Au}_{50.5} \mathrm{Cd}_{49.5}$ マルテンサイト相の結晶構造, (b) $\zeta_{2}$ 相 $c$ 面の断面図. ((a) Crystal Structure of $\zeta_{2}$ ' $\mathrm{Au}_{50.5} \mathrm{Cd}_{49.5}$, (b) Section of $\zeta_{2}{ }^{\prime}-\mathrm{Au}_{50.5} \mathrm{Cd}_{49.5}$ martensite structure.) 
母相の関係を図 2 に示す.母相の $<111>$ がマルテンサイ

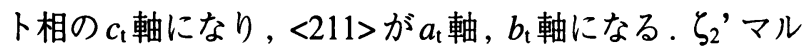
テンサイト相を母相の結晶軸に取り直し，母相の原子位

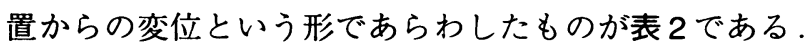
direction と記してあるのは母相のどの方向へ変位してい

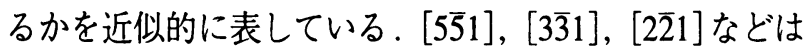
[11̄0] と考えると, 母相の $\mathrm{CsCl}$ 型構造がら2 マルテンサイ ト相になるには図3に示すように\{110\}面が3枚おきに

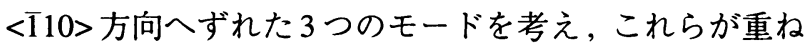
合わさったものを考えると，上に述べたような $c_{\mathrm{t}}$ 軸方向 への原子の変位もうまく説明できる．表 2 にはれらの モードも記してある.これは<1 $10>$ 方向に偏向面を持つ <110>八進む横波変位波の重ねあわせとして記述できる. これは, 多くの $\beta$ 相合金が母相の $\{110\}$ 面がマルテンサイ

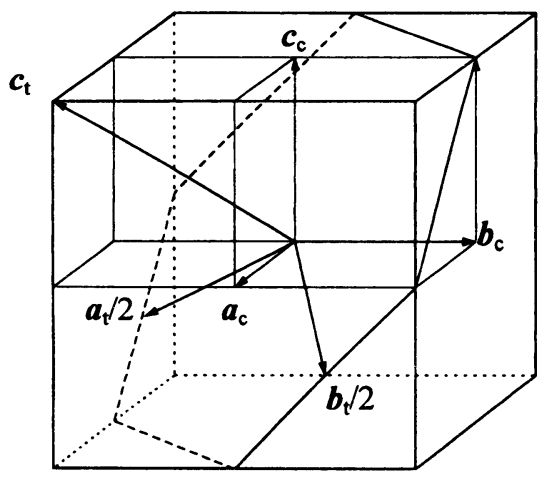

図2 母相とマルテンサイト相の関係.この図では母相の

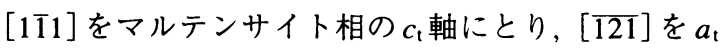
軸, [21̄] を $b_{\mathrm{t}}$ 軸にとってある. (Relation between parent phase and martensitte phase axes. [111] and [121] of the parent phsae are taken to be $c_{\mathrm{t}}$ and $b_{\mathrm{t}}$ axis of the martensite phase, respectively.

表2 立方晶からの原子変位. (Atomic displacements from the ideal positions.)

Atomic Displacements from the Ideal Position

\begin{tabular}{|c|c|c|c|c|c|c|}
\hline & atom & $\mathrm{x}$ & $y$ & z & direction & mode \\
\hline 1 & $\overline{A u(1 a)}$ & 0.000 & 0.000 & 0.000 & & \\
\hline 2 & (1b) & 0.152 & -0.152 & 0.152 & {$[1 \overline{1} 1]$} & $A+B+C$ \\
\hline 3 & (1c) & 0.000 & 0.000 & 0.000 & & \\
\hline 4 & (3d) & 0.042 & -0.105 & 0.102 & {$[1 \underline{2} 2]$} & A \\
\hline 5 & & 0.105 & -0.102 & 0.042 & [221] & C \\
\hline 6 & & 0.102 & -0.042 & 0.105 & {$[2 \overline{1} 2]$} & B \\
\hline 7 & (3d) & 0.067 & -0.067 & -0.005 & {$[1 \overline{1} 0]$} & C \\
\hline 8 & & 0.065 & 0.004 & 0.068 & [101] & B \\
\hline 9 & & -0.004 & -0.068 & 0.065 & {$[0 \overline{1} 1]$} & A \\
\hline 10 & $\mathrm{Cd}(1 \mathrm{a})$ & 0.005 & -0.005 & 0.005 & & \\
\hline 11 & (1b) & 0.146 & -0.146 & 0.146 & [11̄1] & $\mathrm{A}+\mathrm{B}+\mathrm{C}$ \\
\hline 12 & (1c) & 0.005 & -0.005 & 0.005 & & \\
\hline 13 & (3d) & 0.036 & -0.105 & 0.099 & {$[1 \overline{3} 3]$} & A \\
\hline 14 & & 0.105 & -0.099 & 0.036 & {$[3 \overline{3} 1]$} & C \\
\hline 15 & & 0.099 & -0.036 & 0.105 & {$[3 \overline{1} 3]$} & B \\
\hline 16 & (3d) & 0.059 & -0.059 & 0.011 & {$[5 \overline{5} 1]$} & C \\
\hline 17 & & 0.059 & -0.011 & 0.059 & [515] & B \\
\hline 18 & & 0.011 & -0.059 & 0.059 & {$[1 \overline{5} 5]$} & A \\
\hline
\end{tabular}

ト相の稠密面になるような変態をするという事実との整 合性もよく, 都合がよい。

$\gamma_{2}^{\prime}$ ママルテンサイト相は, Ölander ${ }^{24)} に よ り$ 最初に構造 解析が行われ, orthorhombic の構造を持っている.われ われは単結晶を用いてより精密な構造の決定をした.25) 結 晶学的パラメータと原子位置を表 3 に示し, 構造を図 4 に示す．原子はマルテンサイト相稠密面 (001) 面の理想 的な位置からずれており，これは $\mathrm{Au}$ と Cd の原子半径の 違いによると考えられる.26)この結晶構造から類推される 変態のメカニズムは母相の $\{110\}$ 面を交互にずらしたも のとして理解する事ができる。

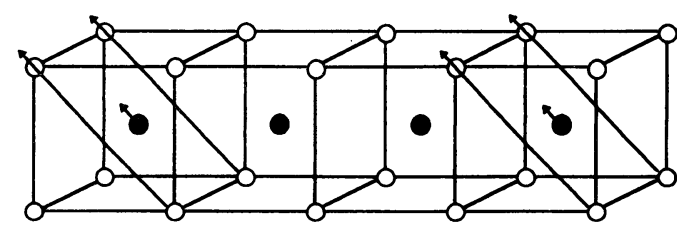

Mode A
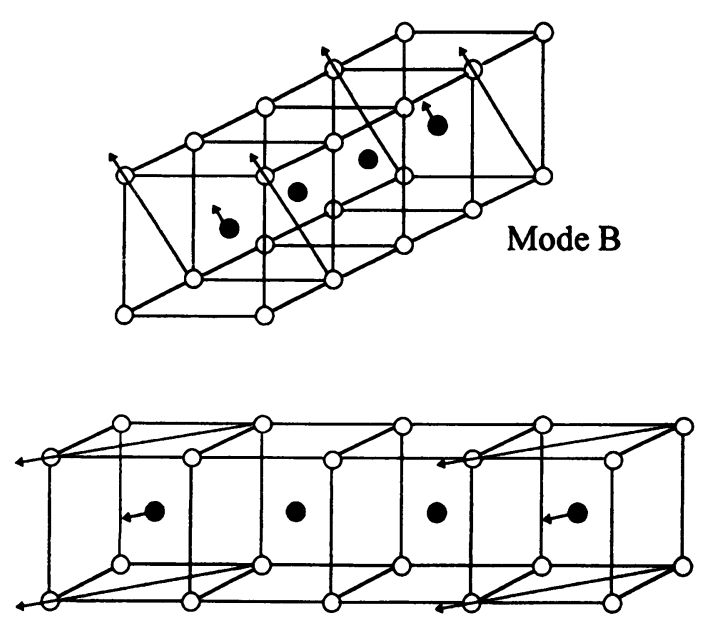

Mode C

図 3 変態に必要な $3 つ の ~\{110\}$ 面の変位. (Three transverse displacement waves.)

表 $3 \gamma_{2}{ }^{\prime}$ 相 $\mathrm{Au}_{52.5} \mathrm{Cd}_{47.5}$ の結晶学的パラメータと原子位置. (Crystal data and atomic parameters of $\gamma_{2}{ }^{\prime} \mathrm{Au}_{52.5} \mathrm{Cd}_{47.5 .}$ )

\begin{tabular}{ll}
\multicolumn{2}{c}{ Crystal Data for $\gamma_{2}{ }^{\prime} \mathrm{Au}_{52.5} \mathrm{Cd}_{47.5}$} \\
\hline Space Group & Pcmm \\
& Orthorhombic \\
\hline Lattice Constants & $\mathrm{a}=4.859(3) \AA$ \\
& $\mathrm{b}=3.151(1) \AA$ \\
& $\mathrm{c}=4.766(1) \AA$ \\
\hline & 4 atoms/cell \\
\hline
\end{tabular}

The Final Atomic Parameters for $\gamma_{2}{ }^{\prime} \mathrm{Au}_{50.5} \mathrm{Cd}_{49.5}$

\begin{tabular}{ccccc}
\hline Site & $\mathrm{x}$ & $\mathrm{y}$ & $\mathrm{z}$ & $\mathrm{B}$ \\
\hline $\mathrm{Au}(2 \mathrm{e})$ & $0.2003(1)$ & 0 & $1 / 4$ & $1.10(3)$ \\
$\mathrm{Cd}(2 \mathrm{f})$ & $0.7050(1)$ & $1 / 2$ & $1 / 4$ & $1.01(5)$ \\
\hline $\mathrm{R}=4.78 \%, w R=5.10 \%$ & & &
\end{tabular}




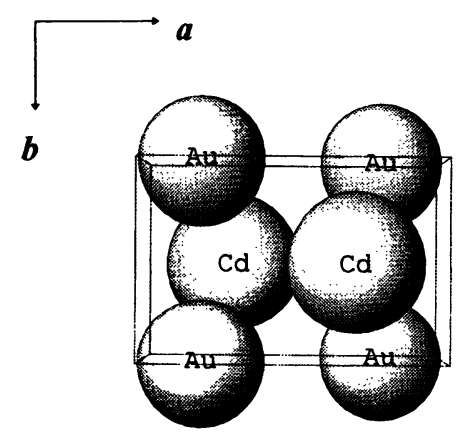

図4 $\gamma_{2}{ }^{\prime}$ 相 $\mathrm{Au}_{52.5} \mathrm{Cd}_{47.5}$ マルテンサイト相の結晶構造. $c$ 軸 方向から見た図. (Crystal structure of $\gamma_{2}{ }^{\prime} \mathrm{Au}_{52.5} \mathrm{Cd}_{47.5}$ martensite.)

\section{3. 中性子散乱実験}

結晶構造から推察すると, AuCd 合金はフォノンのソフ 卜化という考えをうまく適用できそうである.フォノン 分散関係を直接的に観察するのは中性子の非弾性散乱の 実験が一番の方法である。しかし AuCd 合金は中性子散 乱実験には適していない. 特に Cd は中性子の吸収材に 使われており, 通常は中性子の散乱実験を行う事は不可 能である. われわれは $\mathrm{Cd}$ のアイソトープ ${ }^{114} \mathrm{Cd}$ を用いて 母相の単結晶を作製する事によりこの困難を克服し, 中 性子の非弾性散乱の実験を行った.27), 28)

まず $\mathrm{Au}_{50.5} \mathrm{Cd}_{49.5}$ に関して述べる. 結晶構造解析の結果 から<110>へ進む<1 $10>$ 方向に偏向面を持つ横波変位波 が考えられるので[らら0] $\mathrm{TA}_{2}$ モードのフォノン分散関係に 興味が持たれる. 結晶構造から期待されるのは $\zeta=1 / 3$

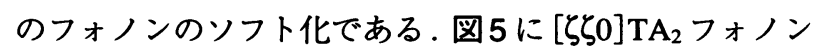
の分散関係を示す. $\zeta=0.35$ に期待されたようにフォノ ンのソフト化が観察された. ソフト化の傾向はすでに 425 Kでも観察され，変態点 $(304 \mathrm{~K})$ に近づくにしたがってフ オノンのエネルギーは小さくなっていく.また，ここで フォノンのエネルギー全体がほかのマルテンサイト変態 する合金に比へ，非常に小さい点は注目に対する.28)

フォノン分散関係の $\approx 0$ 付近の立ち上がりは弾性定 数にあたる. $\mathrm{TA}_{1}$ モードは $c_{44}$ に対応し， $\mathrm{TA}_{2}$ モードは $c_{11}-c_{12}$ に対応し, この比 $A=\frac{2 c_{44}}{c_{11}-c_{12}}$ は弾性異方性といわ れている.Zirnisky ${ }^{299}$ は AuCd 合金の弾性異方性を測定し， 高温から変態温度に向かって行くに従い大きくなると報 告している.フォノン分散関係から求めた弾性異方性を 求めてみるとZirniskyの求めた値とほぼあっている.

また, 母相の $[1+\delta 1-\delta 0] *$ に沿って弾性散乱を観 察すると図6に示すようにソフト化の起こっているとこ ろでいわゆる $1 / 3$ 反射といわれる弾性散乱か観察され，温 度の低下とともに次第にその強度が増す事がわかる。

同様に $\mathrm{Au}_{52.5} \mathrm{Cd}_{47.5}$ についてもアイソトープ ${ }^{114} \mathrm{Cd}$ 用 いた単結晶を作製し, 中性子の非弾性散乱の実験を行っ

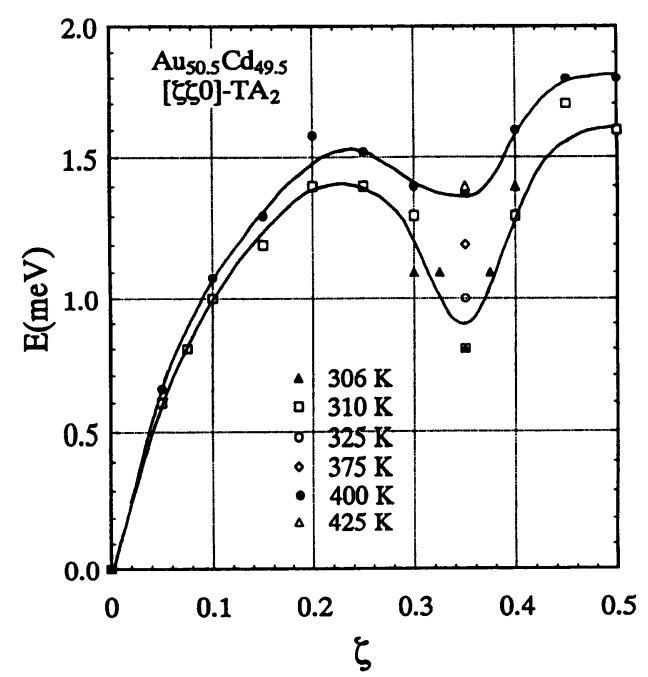

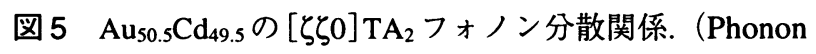
dispersion relation of $[\zeta \zeta 0] \mathrm{TA}_{2}$ branch in $\mathrm{Au}_{50.5} \mathrm{Cd}_{49.5}$.)

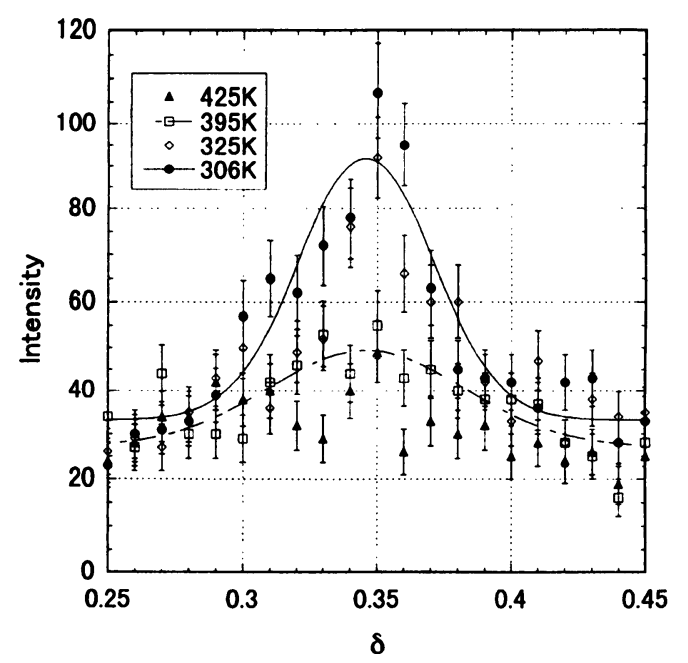

図6 $\mathrm{Au}_{50.5} \mathrm{Cd}_{49.5}$ の方向に測定した $1 / 3$ 反射. $1+\delta 1-\delta 0$ に見られる弾性散乱の温度依存性. (Temperature dependence of the $1+\delta 1-\delta 0$ elastic scattering observed in $\mathrm{Au}_{50.5} \mathrm{Cd}_{49.5 .}$.)

た.30この場合には先にも述べたように $\{110\}$ 面が交互に ずれるとマルテンサイト相を得る事ができるので, 結晶 構造から期待されるフォノンのソフト化は, ブリルアン

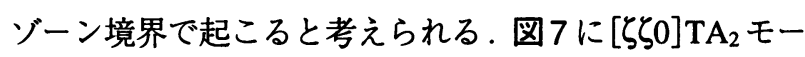
ドのフォノンの分散関係を示す.ブリルアンゾーン境界 では温度の低下とともにフォノンのエネルギーが低下し ており，ソフト化している様子が伺える。この場合には さらにら=0.35 の位置でもフォノンのエネルギーの低下 を見る事ができ,ソフト化が起こっている。これはわず かな組成の違いで生じる $\gamma_{2}{ }^{\prime}$ 相と $\zeta_{2}^{\prime}$ 相が競合し合ってい る事を示していると思われる。

$\gamma_{2}{ }^{\prime}$ 相と $\zeta_{2}{ }^{\prime}$ 相の競合に関して言うと, この組成では熱 


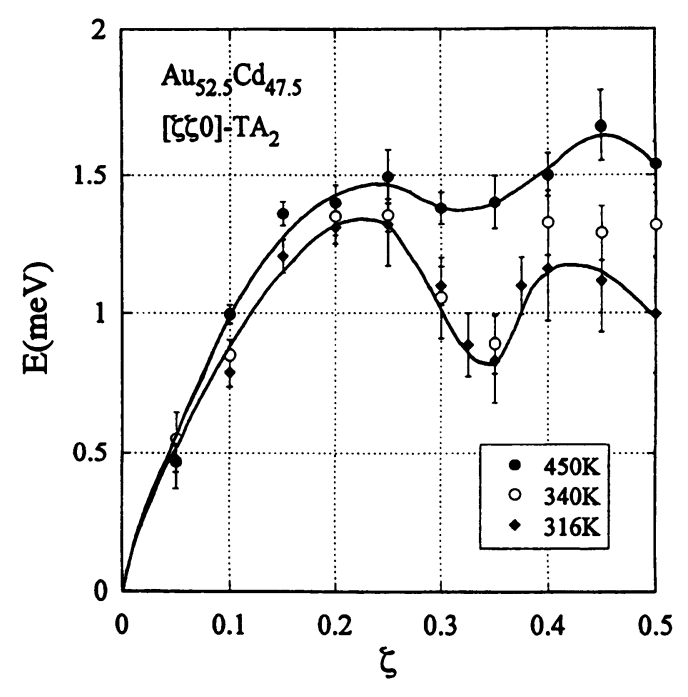

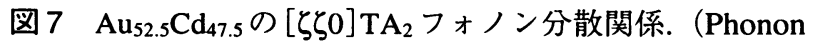
dispersion relation of $[\zeta \zeta 0] \mathrm{TA}_{2}$ branch in $\mathrm{Au}_{52.5} \mathrm{Cd}_{47.5 .}$ )

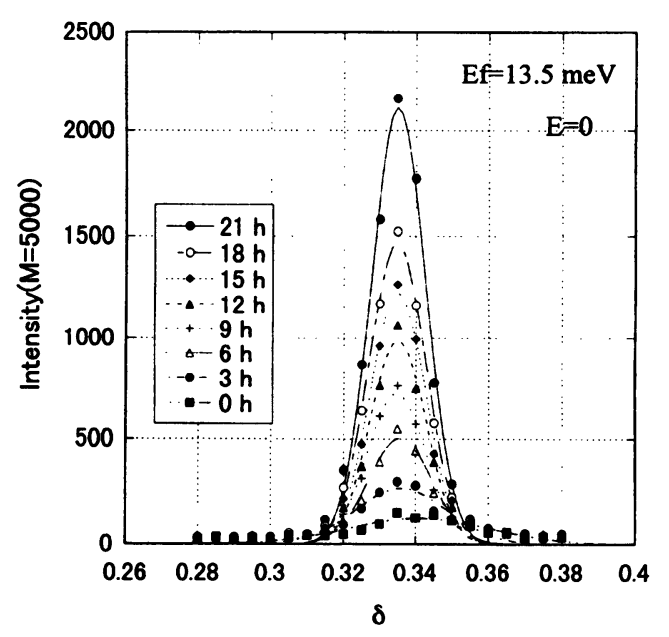

図8 $\mathrm{Au}_{52.5} \mathrm{Cd}_{47.5}$ の [110]*方向に測定した $1 / 3$ 反射. $1+\delta 1-\delta 0$ に見られる弾性散乱の時間依存性.

(Time dependence of the $1+\delta 1-\delta 0$ elastic scattering observed in $\mathrm{Au}_{52.5} \mathrm{Cd}_{47.5}$.)

処理の違いによって二つのマルテンサイト相が現れる事 31)がわかっている. しかし, 今回の試料についてはあら かじめ熱測定により $\gamma_{2}{ }^{\prime}$ 相だけが現れる事を確認した. 試 料の不均一性についても同一インゴットのの中央部分の 一部を用いて熱測定を行い, 鋭い変態温度を得ているの で試料の濃度の不均一も考えられない.したがって,こ の競合は試料の問題ではなく本質的なものである ..

$\mathrm{Au}_{52.5} \mathrm{Cd}_{47.5}$ についてはさらに興味深い現象がわかっ た.30) 図8に $\left[\begin{array}{lll}1+\delta & 1-\delta & 0\end{array}\right] *$ 方向に測定した $\delta=1 / 3$ 反 射の $316 \mathrm{~K}$ での弾性散乱の強度測定の結果を示す. $\gamma_{2}{ }^{\prime}$ マ ルテンサイト相の結晶構造からはこの位置に反射が現れ る事は期待できないが, 図8が示すように反射が現れ, さ らに時間が経つにしたがってその強度を增している。つ
まり $1 / 3$ に現れる弾性散乱は時間依存性を持っているこ とがわかる.30ここの現象に関しては新たに見つかった母相 での時効による変態温度の低下という現象と関わりがあ ると考えているが, 詳しくは参考文献 32), 33)を参照して いただきたい. また, $\zeta=0.35$ のフォノンのソフト化とも 関わりがあると考えられ，さらに研究を進めていく必要 がある。

\section{4. マルテンサイト相の結晶構造について}

マルテンサイト相は母相との結晶方位関係が古くから いわれており，改めてその結晶構造を求める必要もない ような錯覚に陥りやすい. 実際には結晶構造が正しく決 まらないままに，多くの議論がなされてきた合金がある． たとえば形状記憶合金として広く利用されている TiNi 系 合金がそうである．TiNi $(\mathrm{Fe})$ 合金は低温で monoclinic の マルテンサイト相へ変態するが,34, 35) その変態の前駆現 象として, $\mathrm{AuCd}$ 合金と同様に $=1 / 3$ にフォノンのソフ 卜化が起こる事が報告されている.36)-38) 現在では monoclinic のマルテンサイト相へ変態する前に, R 相といわれ る相が存在する事か明らかになっており，フォノンのソ フト化は monoclinic のマルテンサイト相の前駆現象では なく， R 相の前駆現象と考えたほうがよさそうである。

$\mathrm{R}$ 相といわれている理由も，初期のころ母相の立方晶が <111>方向に菱面体的に歪んでできると思われていて，そ のような名称がついたものと考えられる．しかし，最近 の研究によって, 実はこの R 相も $\mathrm{AuCd}$ の $\zeta_{2}$ 相と同様の 空間群を持つ結晶構造である事がわかってきた ${ }^{39)}$ 同様の 構造を持っている事を考えると変態における原子レベル での変位も $\zeta_{2}{ }^{\prime} \mathrm{AuCd}$ と同様であり，立方晶が $<111>$ 方向 に歪んでできるのではない.すでに名前は定着している ので今更混乱を招く必要はないが, R 相という名前は適当 ではないようである．同じようにマルテンサイト相の構 造についている名称が, その対称性を表していないので 戸惑う事がある . 新しい表記法を提案してあるので詳し くは参考文献 40)を参考にしていただきたい.

マルテンサイト相の中には結晶構造がはっきりしてい ない段階から多くの物性が測定されているものがある. 物性科学の発展から考えても仕方のない事かもしれない が，これは結晶学的な観点からすると正しい解釈を与え ない可能性があり危険である．マルテンサイト相の結晶 構造に関する研究は重要でありながら, その結晶構造が 決められなかったのは, 単結晶が得にくかったり，結晶 構造解析に適する粉末試料 (多結晶試料) が得にくい事に 主な原因があると思われる，マルテンサイト恋態に関し ては電子論的なアプローチも行われており, 変態のメカ ニズムやその他いろいろな物性を議論するためには, 結 晶構造の理解が非常に大切な出発点であることを再認識 したい. 


\section{5. おわりに}

マルテンサイト変態のミクロなメカニズムに関して, フォノンのソフト化という見方は非常に魅力的であるが, マルテンサイト相の結晶構造とフォノンのソフト化の関 係がかならずしもよい対応を示していない系が多い。こ のようななかで, AuCd 合金はその対応が非常によく現れ ている系であると考えられる．

また, 中性子散乱の実験では弾性散乱強度の時間依存 性という新たな問題を提起しており，マルテンサイト変 態はいろいろな事柄が複雑に絡み合っているようである。 研究を進める上で当然の事ではあるが，これらをできる だけ正しく, 単純な現象に分けて研究を進めていく事が 必要と思われる。

本研究を遂行するにあたり，絶え間ない御協力をいた だいた筑波大学物質工学系大塚和弘教授に心から感謝い たします.また中性子散乱実験でお世話になった B. N. L. のS. M. Shapiro博士に感謝し, 実験の機会を与えていた だいた学術振興会の日米協力中性子散乱実験に感謝いた します。この研究の一部は文部省科学研究費補助金, 特 定領域研究「相変態」でおこなわれました．

\section{文 献}

1) 舟久保康熙 編：形状記憶合金, 産業図書.

2) M. S. Wechsler, D. S. Lieberman, and T. A. Read: Trans. AIME., 197, 1503 (1953).

3) J. S. Bowles and J. K. Mackenzie: Acta Metall., 2, 129, 138 (1954), Acta Metall., 2, 224 (1954).

4) D. S. Lieberman, M. S. Wechsler and T. A. Read: J. Appl. Phys., 26, 473 (1955).

5) K. Otsuka: Materials Science Forum, 56-58, 393 (1990).

6) K. Otsuka and C. W. Wayman ed.: Shape Memory Materials, Cambridge University Press, 1998.

7) G. V. Kurdjumov and L. G. Khandros: Dokl. Nauk. S.S.S.R., 66, 211 (1949).

8) G. V. Kurdjumov and O. P. Maximova: Dokl. Nauk S.S.S.R., 61, 83 (1949).

9) G. V. Kurdjumov and O. P. Maximova: Dokl. Nauk S.S.S.R., 73, 95 (1950).

10) T. Kakeshita, K. Kuroiwa, K. Shimizu, T. Ikeda, A. Yamagishi and M. Date: Materials Trans. JIM., 34, 423 (1993).

11) H. Abe, M. Ishibashi, K. Ohshima, T. Suzuki, M. Wutting and K. Kakurai: Phys. Rev. 50, 9020 (1994).

12) G. R. Barsch and J. A.Krumhansl: Metall. Trans., 19A, 761 (1988).

13) A. L. Roitburd: Mater. Sci. Eng., A127, 229 (1990).

14) M. Mori, Y. Yamada and G. Shirane: Solid State Commun., 17, 127 (1975).

15) G. Guenin, D. Rios Jara, M. Morin, L. Delaey, R. Pynn and P. F. Gobin: $J$ de Physique, Colloq. C4, suppl., 12, 43, C4-597 (1982).

16) Y. Morii and M. Lizumi: J. Phys. Soc. Jpn., 54, 2948 (1985).

17) Y. Noda, M. Takimoto, T. Nakagawa and Y. Yamada: Metall. Trans., A19, 265 (1988).

18) Y. Yamada, Y. Noda and M. Takimoto: Solid State Commun., 55, 1003 (1985).
19) Y. Yamada: Proc. of International Conference on Martensitic Transformations, Japan Institute of Metals, 89 (1986).

20) W. Köster and A. Schneider: Z. Metallk., 32, 156 (1940).

21) H. M. Ledbetter and C. M. Wayman: Metallurgical Transactions, 3, 2349 (1972).

22) S. Vatanayan and R. F. Hehman: Shape Memory Effects in Alloys, J. Perkins ed., Plenum Press, 1975, New York, p115-p14

23) T. Ohba, Y. Emura and K. Otsuka: Materials Trans. JIM, 33, 29 (1992).

24) A. Olander: Z. Krist., 83A, 145 (1932).

25) T. Ohba, Y. Emura, S. Miyazaki and K. Otsuka: Materials Trans. JIM, 31, 12 (1990).

26) T. Tadak and K. Shimizu: Trans. JIM, 18, 735 (1977).

27) T. Ohba, S.M.Shapiro, S. Aoki and K. Otsuka: Jpn. J. Appl. Phys., 33, L1631 (1994).

28) T. Ohba, S. M. Shapiro, S. Aoki and K. Otsuka: Mat. Res. Soc. Symp. Proc. 376, 701 (1995).

29) S. Zirnisky: Acta Metallugica, 4, 164-171 (1956).

30) T. Ohba, S. Raymond, S. M. Shapiro and K. Otsuka: Jpn. J. Appl. Phys. 37, L64 (1998).

31) T. Suzuki, T. Takagi, A. Nagasawa and N. Nakanishi: J. Mater. Sci., 16, 3013 (1981).

32) X. Ren, T. Ohba, S. Yamada, T. Ishii and K. Otsuka: Proceedings of The Third Pacific Rim International Conference on Advanced Materials and Processing, 12-16, Honolulu, Hawaii, p.1233. (1998).

33) T. Ohba, K. Komachi, K. Watanabe, S. Nakamura and K. Otsuka : submitted to proceedings of ICOMAT-98.

34) G. R. Purdy and J. G. Parr: Tans. Am. Inst. Min. Engrs, 221, 631 (1961)

35) Y. Kudoh, M. Tokonami, S. Miyazaki and K. Otsuka: Acta Metall. 33, 2049 (1985).

36) S. K. Satija, S. M. Shapiro, M. B. Salamon and C. M. Wayman: Phys. Rev., B29, 6031 (1984).

37) P. Moine, J. Allain and B. Renker: J. Phys. F: Met. Phys. 14, 2517 (1984).

38) H. Tietze, M. Müllner and B. Renker : J. Phys. C: Solid State Phys., 17, L529 (1984).

39) T. Hara, T. Ohba, E. Okunishi and K. Otsuka: Materials Trans. JIM, 38, 11 (1997).

40) K. Otsuka, T. Ohba, M. Tokonami and C. W. Wayman: Scripa Mater., 29, 1359 (1993).

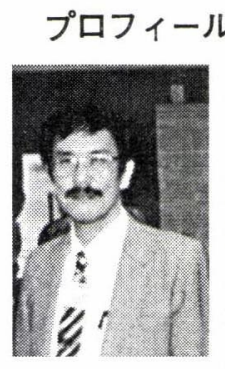

大庭卓也 Takuya OHBA

帝京大学理工学部材料科学工学科

† 320-8551 宇都宮市豊郷台 1-1

Department of Materials Science and Engineering, School of Science and Engineering, Teikyo Univeristy, 1-1, Toyosatodai, Utsunomiya 320-8551, Japan email: ohba@koala.mse.teikyo-u.ac.jp

最終学歴: 広島大学大学院理学研究科物性学専攻 博士課程修了

専門分野: 回折結晶学

現在の研究テーマ：マルテンサイト変態の結晶学 的研究

趣味：写真撮影(だった？) 